\title{
The Impact of Merger and Acquisition on Customer Satisfaction in Post- Merger Phase in Banking Sector of Nepal
}

\author{
Krishna Prasad Sharma* \\ Received on 28 August 2018; Revised on 25 October 2018; Accepted on 2 December 2018
}

\begin{abstract}
Mergers and acquisitions among financial institutions have been increased due to the introduction of merger by-law in May 2011 and capital enhancement through monetary policy of Nepal Rastra Bank in 2015. Bank and financial institutions need to be fully approachable and reactive that banking merger has not hampered customer service. Since the entire business depends on the customer's positive feedback and satisfaction, good customer service is essential in this kind of business. It is always being argued that the impact of mergers and acquisitions on the customer is difficult to measure due to the direct influence of external factors like global competition or technological advancement. Bearing this consideration, the paper evaluates the impact of bank mergers and acquisitions on customers by using survey method. Customer satisfaction and service quality after mergers have been measured by summative scale calculated by a simple arithmetic mean and by using the weighted average method. Similarly, five point Likert-type scales have been used for measuring the satisfaction level of customer. Customers were asked to rank the various factors affecting satisfaction level on the five point scale which was further analyzed using SPSS and MS Excel. Results suggest that the merger program was successful from customers' point of view in Nepal because it has benefited them through economies of scale, expansion of working area and advancement in technology. Another perspective regarding the service quality of banks in post-merger found that customers are enjoying competitive interest rate due to the enhanced capital base.
\end{abstract}

Keywords: Bank and financial institutions, customer satisfaction, merger and acquisition, Nepal Rastra Bank, service quality.

\section{INTRODUCTION}

Merger and acquisition (M\&A) activities increased dramatically in Nepal after the issuance of merger by-law in the year 2011. Similarly, the monetary policy of 2015 became another pathway for banking sectors to adopt merger and acquisition as it instructed to hike paid up capital of banks by almost four times. Commercial banks had to hike their paid-up capital to Rs.8 billion from the current Rs 2 billion, National level development banks to Rs.2.5 billion from Rs.640 million and national level finance companies to Rs.800 million from Rs. 200 million. Banks today have more emphasized on financial aspect for merger not the human factors. The study highlights the impact of M\&A on the customers as banks and financial institutions (BFIs) are the service rendering organizations and their success are largely depends on customers satisfaction.

Post-M\&A technology integration, upgrade or deployment needs to be carefully planned to ensure

*Mr. Sharma is doctoral research scholar in Singhania University, Rajasthan, India.

E-mail: krishnazee@gmail.com 
minimal disruption to service delivery (Fashola, 2014). M\&As have emerged as the most preferred long term strategy of corporate restructuring and strengthening in the present globalized world. The main rationale behind the M\&A is to create a synergy that is one plus one is more than two. Banking sector plays a crucial role in the economic growth and development of a nation. Globalization, deregulation of the economy coupled with technological development has changed the banking landscape dramatically but one has to be cautioned on the customer's satisfaction as well. However, with the fast changing environment, the banking sector is resorting to the process of consolidation, corporate restructuring and strengthening to remain efficient and viable.

The objective of the paper is to evaluate the satisfaction level of customer of merged banks in Nepal. Further, the research tends to assess the reason behind dissatisfaction of customer and to study the quality of banking service in post-merger phase. Similarly, the research suggests a framework in order to extend customers' satisfaction by Nepalese BFIs in post-merger phase.

\section{LITERATURE REVIEW}

Many journals articles have been available in the area of merger and acquisition and many institutional or individual researchers have studied the impact of the merger in customer satisfaction and some of them are as follows:

Clifford and Rowley (1999) have mentioned in their review that on December 14, 1998, the Canadian Minister of Finance announced that two high profile bank mergers would not be allowed to proceed because they were not "in the best interests of Canadians". The Minister's decision was found on three conclusions: a) the mergers would lead to an unacceptable concentration of economic power in the hands of a few banks; $b$ ) the mergers would result in a significant reduction of competition; and c) the mergers would reduce the government's policy flexibility to address potential future prudential concerns.

Conyon, Girma, Thompson and Wright (2000) have provided a systematic empirical analysis of the effects of take-over and merger activity on firm employment in the United Kingdom using a specially constructed database for the period 1967-1996. Results have indicated that significant rationalizations in the use of labour occur as firms reduce joint output and increase efficiency post-merger. These effects are particularly pronounced in the case of related and especially hostile mergers.

Sufian (2004) has used the non-parametric frontier approach, Data Envelopment Analysis (DEA) to analyze the technical and scale efficiency of domestic incorporated Malaysian commercial banks during the merger year, pre-and post-merger period. His study showed that Malaysian banks have exhibited a commendable overall efficiency level of 95.9 percent during 1998-2003, hence suggesting minimal input waste of 4.1 percent. Results suggest that the merger program was successful, particularly for the small and medium size banks, which have benefited the most from the merger and expansion via economies of scale. On the other hand, results suggest that the larger banks should shrink to benefit from scale advantages. Decision-makers hence ought to be more cautious in promoting mergers as a means of enjoying efficiency gains.

Ayo, Ekong, Fatudimu, and Adebiyi (2007) affirmed the influence of information and communications technology (ICT) on post-consolidation banking service provision to customers which have enhanced effectiveness and efficiency and led to the introduction of techno-products and services such as electronic cards, Internet banking and mobile banking services.

Oberg (2008) has researched M\&As from M\&A parties' and customers' perspectives. The researcher 
has categorized and connected M\&A parties' activities related to expectations and activities of customers, with customers' activities at the acquisition point and at integration. Based on findings from eight M\&As, the study concludes that customers may be the reasons why companies merge or acquire. Customers may react to the $M \& A$ announcement if it involves companies the customers do not want to have relationships with, or based on the fact that customers perceive the M\&A as turbulent, for instance. Customer actions, and M\&A parties reconsidering their initial intentions affect integration strategies. The realization of integration is in turn impacted by customers' resistance to buy according to M\&A parties' intentions and by customers actively objecting to integration.

Garriga (2008) found that continuing borrowers benefit from mergers in terms of reduced loan rates. Small and young firms enjoy the highest decline in interest rates. The most beneficial mergers from the borrower point of view are those involving two large banks, which is not consistent with the existence of a "size effect" in lending. On the one hand, mergers are harmful to small businesses because lending relationships are more likely to be disrupted following a merger. Small borrowers of target banks have a higher probability of losing a relationship with the consolidated bank. Moreover, small borrowers find it harder to start a new lending relationship with consolidated banks. In sum, the higher termination rate for existing borrowers is not compensated with a higher initiation rate of new lending relationships with small businesses after the merger.

Prompitak (2009) has used the data set of large European commercial banks from 1997 to 2005 to explain the effects of mergers on bank loan pricing behavior, interest margin setting, credit availability and lending objectives. The analysis provides evidence that mergers have statistically significant influence on reduced lending rates, interest margins and loan supply. These results suggest that merged banks can obtain efficiency gains through mergers and can pass these benefits to their customers in the form of lower lending rates and interest margins.

Subrahmanya (2011) states cross-selling opportunities arising from mergers leading to increased revenues and profits and more intensive use of customer data base to identify new opportunities for differential promotion.

Rating revealed a better score for acquisition bank's customers than merged bank's customers. An outcome attested to by a superior majority of acquisition bank's customers agrees that they were more satisfied post-acquisition than the proportion of merged bank's customers that agreed they were more satisfied post-merger (Fashola, 2014).

Wang, Shih and Lin (2014) have investigated the long-run post-merger performance of Asian acquiring bank by using 293 deals in the 1997-2007 periods. Researchers found that the Asian acquiring banks have experience of negative long-term abnormal returns and are not efficiency improving, followed by mergers and acquisition. In general, the long-run stock performance and operating performance of Asian commercial bank's merger and acquisition are negative and Asian commercial bank's merger and acquisition cannot create synergy in the long run.

Chen and Vashishtah (2015) have studied the mergers and acquisitions waves in the U.S. banking industry to study the effect of bank market structure on borrowers' disclosure. Applying a differencein-differences approach to explore variations in the timing of bank mergers, researchers have found a significant increase in borrowing firms' disclosure when their lead banks engage in merger and acquisition activities. In addition to that, although the disclosure increase is larger for borrowers that increase reliance on public debt, it is not limited to them and even manifests for borrowers that do not experience an increase in public debt or decrease in credit availability. 
Similarly, Joash and Njangiru (2015) argue that merger and acquisition enhances the stability and effectiveness of operations of the organization and thereby increases the customer's satisfaction.

Further, mergers and acquisitions expand the capital base of the organization thus enabling the organization to access more resources and especially credit facilities that ensure that the business is liquid throughout the year. This enhances the stability and effectiveness of operations of the organization increasing the customer's satisfaction (Joash \& Njangiru, 2015).

Ojha and Walsh (2016) have opined that mergers in recent years have helped most of the financial institutions to increase the capital as well as becoming more competitive. However, the most important consequences after merger have become the protection of consumer right and the banking sectors have become sufficiently able to safeguard themselves in critical financial positions.

\section{DATA AND METHODS}

This research is descriptive and based on primary data. However, both primary and secondary data have been used to study the impact of merger and acquisition in customers' satisfaction. Primary data was collected by means of questionnaires. The details about M\&A concept in the banking sector were discussed with the official of different merged BFIs. Similarly, the secondary data were collected from a wide array of research papers, capital market, journals, magazines, website, and company's data base and so on. The survey method was used to interpret the primary data collected from respondents using close bounded questionnaire. Data were analyzed and presented quantitatively using MS-Excel and SPSS.

To identify the impact of M\&A on the customer of the merged entity, an online survey questionnaire was designed using Google forms which contain rating options, multiple choice questions as well as close ended questionnaires. The questionnaires were distributed to the customer of merged bank directly through messenger and WhatsApp applications available in smart phones. By doing so, the customers can freely express their ideas and opinions.

The surveyor collected the information from those customers who had been banking with bank before merger to its post-merger phase. The surveyor distributed questionnaires through messenger and WhatsApps from July 2018 to the end of August 2018 and collected 95 responses. Out of 95 retrieved responses, four were rejected and 91 were analyzed using SPSS and MS Excel.

Structural questionnaires were used for primary data collection. Five point Likert-type scales were used for measuring the satisfaction level of customer. Customers were asked to rank the various factors affecting satisfaction level on the five point scale i.e. 1 to 5 . Where 1 denotes strongly disagree, 2 denotes disagree, 3 denotes neutral, 4 denotes agree and 5 denotes strongly agree. Scores of all respondents were compiled then weighted mean was calculated for every factor affecting in post-merger phase. Ranking of weighted mean scores was used to find out the major customer satisfaction and service quality to the customer in post-merger phase.

Similarly, customer satisfaction and service quality after the merger were measured through a summative scale calculated by a simple arithmetic mean.

$\bar{x}=\frac{\sum x i}{n}$

Satisfaction and service quality was supposed to satisfy scoring average scale $\geq 3$. Surveyor also tried to find the reason for dissatisfaction. 


\section{RESULTS AND DISCUSSIONS}

Table 1 shows the growth of financial institutions in Nepal. Mergers and acquisitions have become the preferred strategy for growth in the size of banks which, in turn plays a significant role in entering the global financial market. By the end of mid-July 2011 altogether 218 banking financial institutions licensed by Nepal Rastra Bank were in operation. As soon as the government of Nepal issued the merger by-law, the number of banks by the end of mid-July, 2018 reduced to 151. Out of them, 28 are "A' class commercial banks, 33 are "B" class development banks, 25 are "C" class finance companies and 65 are " $D$ " class micro-credit development banks. Therefore, the research purposes to measure the satisfaction level of customer of Nepalese BFIs by randomly collected questionnaires from the customers.

Table 1

Growth of Financial Institution in Nepal

\begin{tabular}{lccccccccc}
\hline \multirow{2}{*}{ Types of BFIs } & \multirow{2}{*}{ Class } & \multicolumn{10}{c}{ Mid- July } \\
\cline { 3 - 10 } & & 2011 & 2012 & 2013 & 2014 & 2015 & 2016 & 2017 & 2018 \\
\hline Commercial banks & $\mathrm{A}$ & 31 & 32 & 31 & 30 & 30 & 28 & 28 & 28 \\
Development banks & $\mathrm{B}$ & 87 & 88 & 86 & 84 & 76 & 67 & 40 & 33 \\
Finance companies & $\mathrm{C}$ & 79 & 69 & 59 & 53 & 47 & 40 & 28 & 25 \\
$\begin{array}{l}\text { Micro-finance } \\
\text { development bank }\end{array}$ & $\mathrm{D}$ & 21 & 24 & 31 & 37 & 38 & 42 & 53 & 65 \\
\hline Total & & & & & & & & & \\
\hline
\end{tabular}

Source: Bank Supervision Report and Banking and Financial Statistics of Nepal Rastra Bank.

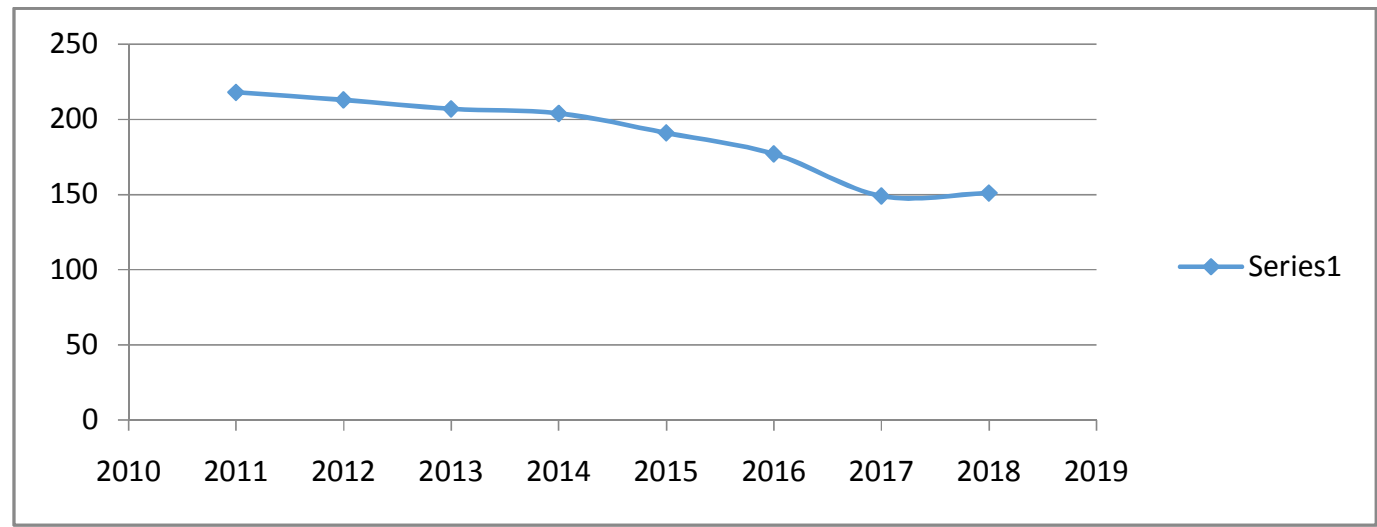

Figure 1. Growth of financial institutions in Nepal.

The survey was conducted to analyze the impact of the merger of the bank on the customer. Table 2 shows the percentage of the respondents in each section based on various demographics like age, gender, marital status and years of association with banks. This study includes a survey of 91 respondents. Among the 91 respondents, 57 had been associated with the bank for more than four years, four between three to four years, 14 between two to three years, eight between one to two years and eight less than one year. There were 61 males and 30 females responding to the questionnaires. 47 respondents were aged below 30, 35 were between 31 to 40,7 respondents between 41 to 50 and two respondents were 50 years above. Of them 58 were married and 33 were unmarried. Questionnaires were distributed and collected 
only from those customers who had been banking associations with the bank before merger to its postmerger phase.

Table 2

Demography of Respondents with Percentage

\begin{tabular}{|c|c|c|c|c|c|c|c|c|c|c|c|}
\hline \multicolumn{3}{|c|}{$\begin{array}{c}\text { Years of association } \\
\text { with bank }\end{array}$} & \multicolumn{3}{|c|}{ Age-wise } & \multicolumn{3}{|c|}{ Gender-wise } & \multicolumn{3}{|c|}{$\begin{array}{l}\text { According to } \\
\text { marital status }\end{array}$} \\
\hline Year & No & $\%$ & $\begin{array}{l}\text { Age } \\
\text { (Yrs.) }\end{array}$ & No & $\%$ & Gender & No & $\%$ & $\begin{array}{c}\text { Marital } \\
\text { status }\end{array}$ & No & $\%$ \\
\hline 1 year & 8 & $9 \%$ & $\begin{array}{l}\text { Less } \\
\text { than } 30\end{array}$ & 47 & $52 \%$ & M & 61 & $67 \%$ & Married & 58 & $64 \%$ \\
\hline 2 years & 8 & $9 \%$ & $31-40$ & 35 & $38 \%$ & $\mathrm{~F}$ & 30 & $33 \%$ & Single & 33 & $36 \%$ \\
\hline 3 years & 14 & $15 \%$ & $41-50$ & 7 & $8 \%$ & & & & & & \\
\hline 4 years & 4 & $4 \%$ & $\begin{array}{c}\text { Above } \\
50\end{array}$ & 2 & $2 \%$ & & & & & & \\
\hline $\begin{array}{l}4 \text { years } \\
\text { above }\end{array}$ & 57 & $63 \%$ & & & & & & & & & \\
\hline Total & 91 & $100 \%$ & & 91 & $100 \%$ & & 91 & $100 \%$ & & 91 & $100 \%$ \\
\hline
\end{tabular}

Associated with Bank and Financial Institutions

Table 3 reveals the basis of customers' association with bank and financial institution;

Table 3

Associated with BFIS

\begin{tabular}{lcccc}
\hline Response & As a borrower & As a depositor & Both/others & Total \\
\hline No of respondents & 16 & 46 & 29 & 91 \\
Percentage $(\%)$ & $18 \%$ & $51 \%$ & $32 \%$ & $100 \%$ \\
\hline
\end{tabular}

Source: Field survey, 2018

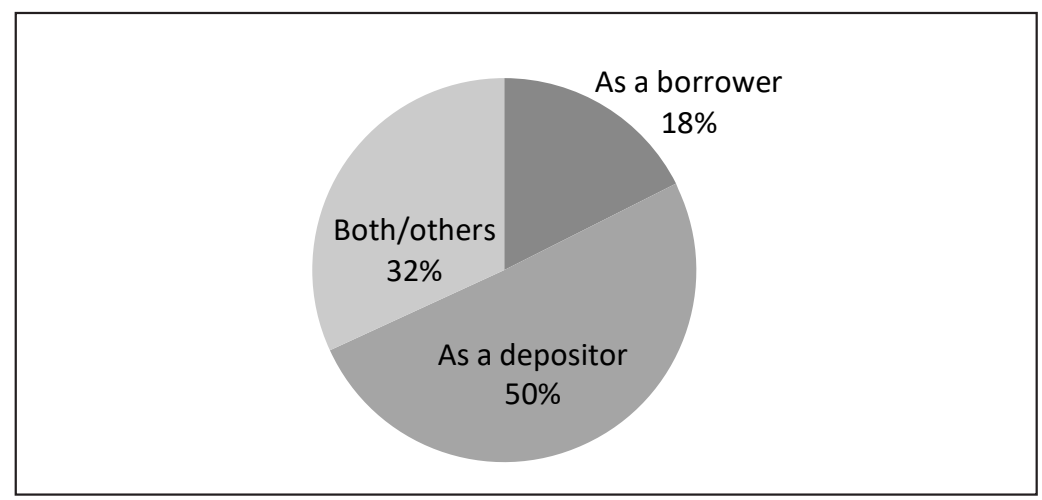

Figure 2. Associated with bank and financial institutions. 
Figure 2 shows that out of total respondent, 50 percent were associated with bank as a depositor, 18 percent were associated as borrower and rest 32 percent were associated either as both i.e. borrower and depositor or through other means like remitting customer and so on.

\section{No Feeling of Discrimination}

A question was asked to all the respondents that merger and acquisition do not create discrimination in rendering service in post-merger phase.

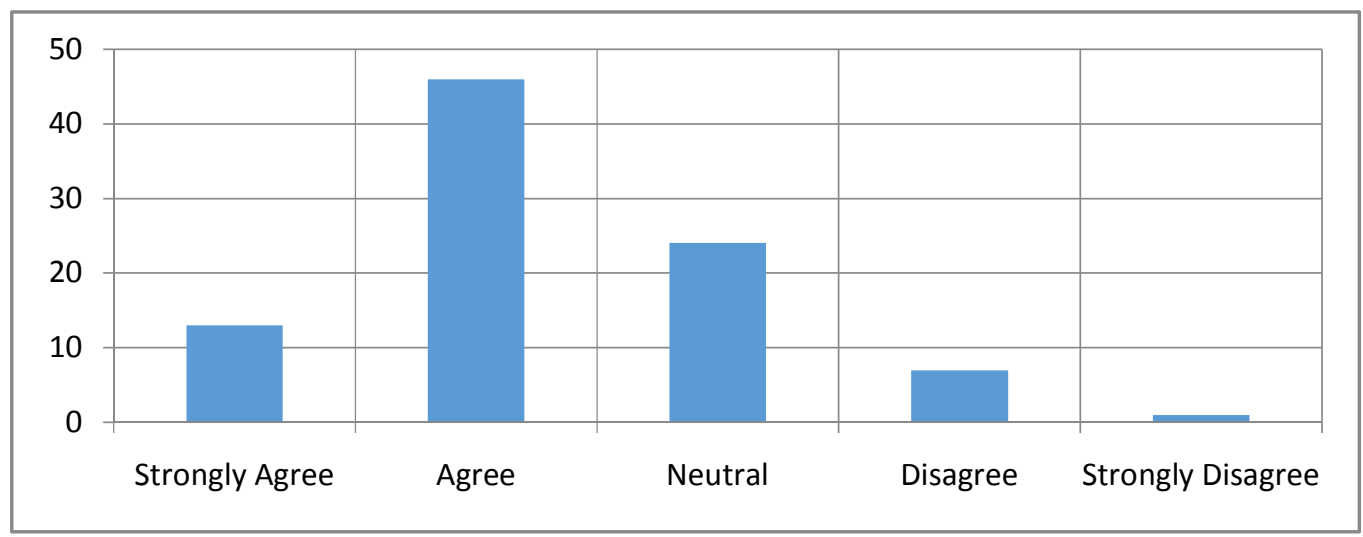

Figure 3.M\&A create no discrimination in post-merger phase

Figure 3 shows that 91 percent of respondent have either strongly agreed, agreed or neutral that there is no discrimination in services to customers of merged or acquired bank being rendered by BFIs in postmerger phase. However, only 9 percent of respondents do not have the same opinion.

\section{Need of Merger and Acquisition Notice to Customers}

A question was asked to all the respondents regarding the need of merger notice to public.

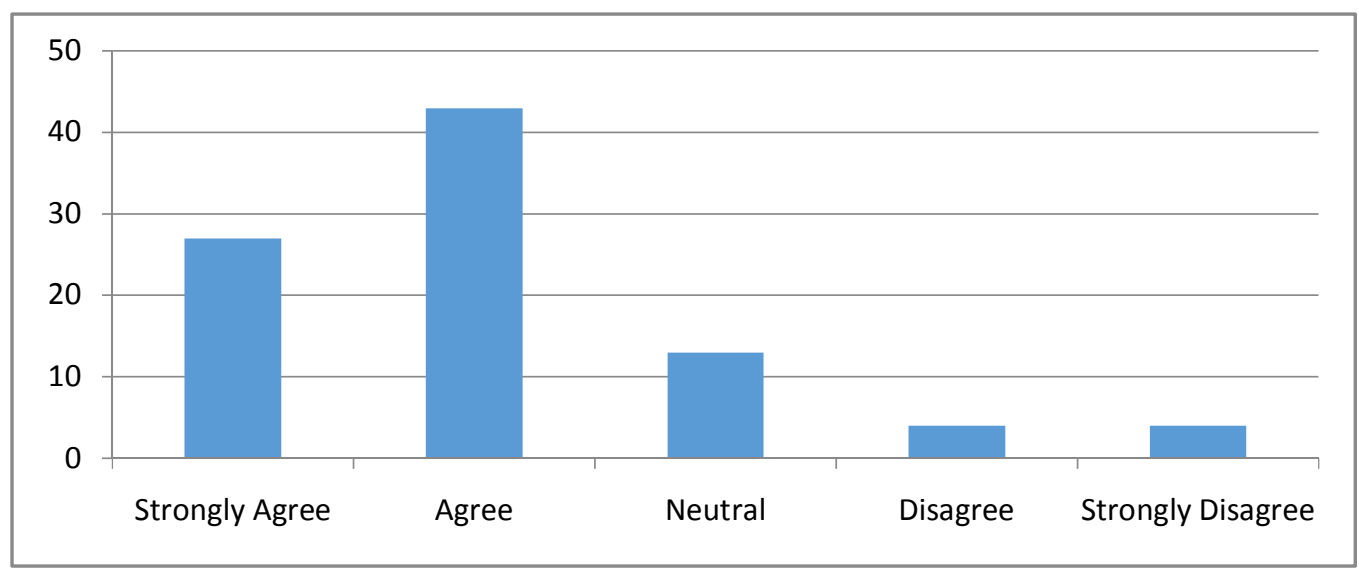

Figure 4. Need of merger and acquisition notice 
Figure 4 witnessed, 91 percent of respondent have strongly agreed, agreed or neutral that the company should make a public notice to customer regarding merger and acquisition. However, as per merger law by 2017, a pre notice within 30 days of merger or acquisition's decision was published for two times in a national level newspaper stating the date of joint operation.

\section{Customer Satisfaction in Post-Merger Phase}

Customers were asked to rank the various factors affecting satisfaction level on the five point scale i.e. 1 to 5 . Here, 1 denotes strongly disagree, 2 denotes disagree, 3 denotes neutral, 4 denotes agree and 5 denotes strongly agree. Scores of all respondents were compiled then weighted mean was calculated for every factor. Ranking of weighted mean scores was done to find out the major satisfaction category of customer.

Table 4 reveals the service quality of banks and financial institutions to customer in post-merger phase:

Table 4

Customer Satisfaction in Post-Merger Phase

\begin{tabular}{|c|c|c|c|c|c|c|c|c|c|}
\hline Factors & SA & A & $\mathrm{N}$ & $\mathrm{D}$ & SD & Total & $\begin{array}{l}\text { Weighted } \\
\text { total }\end{array}$ & $\begin{array}{l}\text { Weighted } \\
\text { mean }\end{array}$ & Rank \\
\hline $\begin{array}{l}\text { 1. Customer's relationship } \\
\text { management gets better after } \\
\text { merger }\end{array}$ & 7 & 43 & 20 & 18 & 3 & 91 & 306 & 20.40 & 8 \\
\hline $\begin{array}{l}\text { 2. Customer's satisfaction in } \\
\text { economic terms }\end{array}$ & 0 & 48 & 31 & 11 & 1 & 91 & 308 & 20.53 & 7 \\
\hline $\begin{array}{l}\text { 3. No difficulty for the existing } \\
\text { depositors to maintain banking } \\
\text { relationship in post-merger phase }\end{array}$ & 8 & 43 & 16 & 19 & 5 & 91 & 303 & 20.20 & 9 \\
\hline $\begin{array}{l}\text { 4. No difficulty for the existing } \\
\text { borrowers to maintain banking } \\
\text { relationship in post-merger phase }\end{array}$ & 4 & 45 & 17 & 22 & 3 & 91 & 298 & 19.87 & 10 \\
\hline $\begin{array}{l}\text { 5. Rendering modern services to } \\
\text { their customer after M\&A }\end{array}$ & 6 & 51 & 26 & 7 & 1 & 91 & 327 & 21.80 & 4 \\
\hline $\begin{array}{l}\text { 6. No partiality in service rendered } \\
\text { in post-merger phase }\end{array}$ & 8 & 48 & 14 & 20 & 1 & 91 & 315 & 21.00 & 5 \\
\hline $\begin{array}{l}\text { 7. Banking M\&A has neither } \\
\text { restricted competition and nor } \\
\text { created monopoly }\end{array}$ & 10 & 40 & 24 & 13 & 4 & 91 & 312 & 20.80 & 6 \\
\hline $\begin{array}{l}\text { 8. Goodwill of the bank is enhancing } \\
\text { after M\&A. }\end{array}$ & 15 & 48 & 19 & 6 & 3 & 91 & 339 & 22.60 & 3 \\
\hline $\begin{array}{l}\text { 9. M\&A increases the range of } \\
\text { products available. }\end{array}$ & 14 & 56 & 14 & 6 & 1 & 91 & 349 & 23.27 & 1 \\
\hline $\begin{array}{l}\text { 10. More numbers of Branches and } \\
\text { ATM after merger has helped in } \\
\text { improving customer service in } \\
\text { post-merger phase. }\end{array}$ & 14 & 56 & 14 & 6 & 1 & 91 & 349 & 23.27 & 1 \\
\hline
\end{tabular}




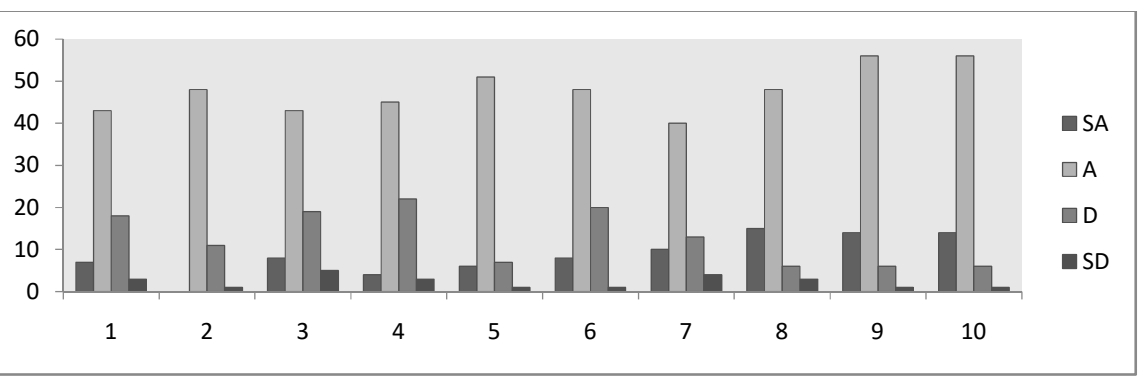

Figure 5.Customer satisfaction in post-merger phase.

As seen in Table 4 and Figure 5, customers believe that merger and acquisition have positive impact on service rendered by BFIs in post-merger phase. It is believed that merger and acquisition have increased the ranges of product available, number of branches, ATM counters, goodwill, modern services, and so on.

\section{Service Quality in Post-Merger Phase to Customer}

Customers were asked to rank the various factors affecting satisfaction level on the five point scale (i.e. 1 to 5), where 1 denotes strongly disagree, 2 denotes disagree, 3 denotes neutral, 4 denotes agree and 5 denotes strongly agree. Scores of all respondents were compiled then weighted mean was calculated for every factor affecting service quality in post-merger phase. Ranking of weighted mean scores was done to find out the major service quality to the customer in the post-merger phase.

Table 5 reveals the service quality of banks and financial institutions to the customer in the postmerger phase as mentioned below:

Table 5

Service Quality to Customer in Post-Merger Phase

\begin{tabular}{lrrrrrrrrrc}
\hline \multicolumn{1}{c}{ Factors } & SA & A & N & D & SD & Total & $\begin{array}{c}\text { Weighted } \\
\text { total }\end{array}$ & $\begin{array}{c}\text { Weighted } \\
\text { mean }\end{array}$ & Rank \\
\hline High interest in deposit & 2 & 11 & 36 & 32 & 10 & 91 & 236 & 15.73 & 4 \\
Low interest in loan & 0 & 14 & 31 & 38 & 8 & 91 & 233 & 15.53 & 5 \\
Decrease in service charge of loan & 0 & 8 & 38 & 34 & 11 & 91 & 225 & 15.00 & 6 \\
Number of ATM counter and branch & 22 & 35 & 22 & 7 & 5 & 91 & 335 & 22.33 & 1 \\
has been increased & 17 & 33 & 27 & 9 & 5 & 91 & 321 & 21.40 & 2 \\
Adoption of new technology & 4 & 20 & 44 & 15 & 8 & 91 & 270 & 18.00 & 3 \\
No charge and fees monopoly & & & & & & & & & & \\
\hline
\end{tabular}

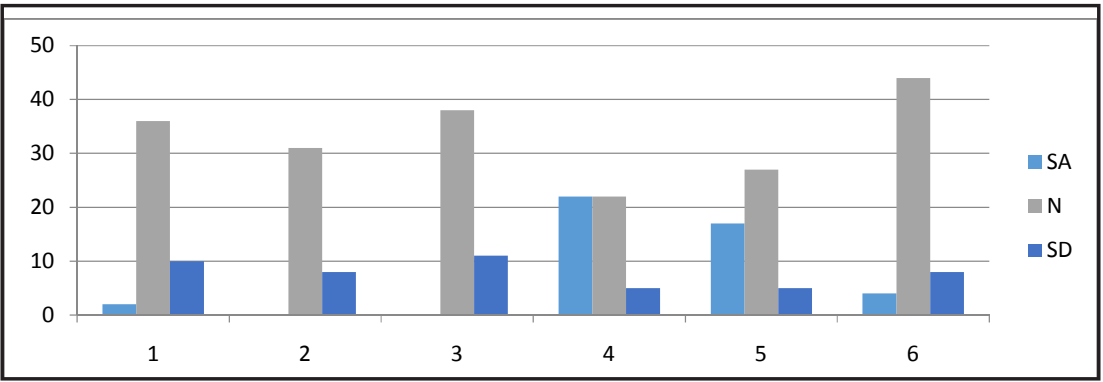

Figure 6. Service quality to customer in post-merger phase 
As seen in Table 5 and Figure 6, customers trust that merger and acquisition have positive impact in service quality by BFIs in post-merger phase. It is believed that merger and acquisition have increased the number of branches and ATM. They have adopted new technology, no monopoly in service, taking competitive service charge, and so on.

\section{Measuring Customer's Satisfaction and Service Quality using Summative Scale}

Customer's satisfaction and service quality have been measured by summative scale assuming scoring $\geq 3$ are satisfied. Customers were asked to rank the various factors affecting satisfaction level and service quality in post-merger phase on the five point scale (i.e. 1 to 5), where 1 denotes strongly disagree, 2 denotes disagree, 3 denotes neutral, 4 denotes agree and 5 denotes strongly agree. Scores of all respondents for different factors were summed and average was calculated by simple arithmetic mean for every respondent separately. Respondents getting $\geq 3$ were supposed to be satisfied in post-merger phase.

\section{a. Measuring Customer Satisfaction in Post-merger Phase}

Out of 91 respondents, 78 respondents scored $\geq 3$ so 13 Likert-scale questionnaires were summed and an average was calculated to find the reason of customer dissatisfaction in the post-merger phase which is shown in Table 6.

$$
\begin{aligned}
& \text { Here, } \bar{x}=\frac{\sum x i}{n} \\
& \bar{x}=\frac{78}{91}=85.71 \%
\end{aligned}
$$

\section{b. Measuring Service Quality in Post-merger Phase}

Out of 91 respondent 51 respondents scored $\geq 3$ so 40 Likert-scale questionnaires were summed and an average was calculated to find the reason of unsatisfied respondent under service quality in postmerger phase which is shown in Table 7.

$$
\begin{aligned}
& \text { Here, } \bar{x}=\frac{\sum x i}{n} \\
& \bar{x}=\frac{51}{91}=56.04 \%
\end{aligned}
$$

Here, customers seemed satisfied in either aspect scoring 85.71 percent and 56.04 percent which is more than 50 percent. Thus, customer of Nepalese bank and financial institutions seemed satisfied in post-merger phase.

\section{Reason for Customer Dissatisfaction}

Analysis shows 85.71 percent of customer seemed satisfied in banking service in post-merger phase whereas 56.04 percent of customers are satisfied with service quality. However, only 14.29 percent (100\%-85.71\%) are not satisfied with customer server and 43.96 percent $(100 \%-56.04 \%)$ of respondents seemed unsatisfied in service rendered by BFIs in post-merger phase by Nepalese BIFs. Table 6 disseminates the reason behind customer dissatisfaction in post-merger phase.

Table 6 reveals that out of 91 respondents 13 respondents did not seem satisfied on customer service in post-merger phase. In addition, borrowerswere fully satisfied in post-merger phase, whereas 23 percent of depositors and 77 percent of other customers who were associated with bank through various services seemed unsatisfied. Similarly, 62 percent of male and 38 percent of female were not satisfied 
Table 6

Demography of Unsatisfied Respondent under Customer Satisfaction

\begin{tabular}{|c|c|c|c|c|c|c|c|c|c|c|c|}
\hline \multicolumn{3}{|c|}{$\begin{array}{c}\text { According to } \\
\text { customer types }\end{array}$} & \multicolumn{3}{|c|}{ Age-wise } & \multicolumn{3}{|c|}{ Gender-wise } & \multicolumn{3}{|c|}{$\begin{array}{l}\text { According to } \\
\text { marital status }\end{array}$} \\
\hline $\begin{array}{c}\text { Types of } \\
\text { Customers }\end{array}$ & No & $\%$ & $\begin{array}{c}\text { Age } \\
\text { Group }\end{array}$ & No & $\%$ & Gender & No & $\%$ & $\begin{array}{c}\text { Marital } \\
\text { status }\end{array}$ & No & $\%$ \\
\hline Depositor & 3 & $23 \%$ & $\begin{array}{c}\text { Less } \\
\text { than } 30\end{array}$ & 0 & $0 \%$ & Male & 8 & $62 \%$ & Married & 8 & $62 \%$ \\
\hline Borrower & 0 & $0 \%$ & $31-40$ & 4 & $31 \%$ & Female & 5 & $38 \%$ & Single & 5 & $38 \%$ \\
\hline $\begin{array}{l}\text { Both/ } \\
\text { Others }\end{array}$ & 14 & $77 \%$ & $\begin{array}{c}41 \\
\text { Above }\end{array}$ & 9 & $29 \%$ & & & & & & \\
\hline Total & 13 & 100 & & 13 & 100 & & 13 & 100 & & 13 & 100 \\
\hline
\end{tabular}

in post-merger phase. Likewise 62 percent of married customers and 38 percent of unmarried customers were not satisfied. Also, the table represents those customers below 30 years of age were fully satisfied in post-merger phase.

Table 7

Demography of Unsatisfied Respondent Under Service Quality

\begin{tabular}{|c|c|c|c|c|c|c|c|c|c|c|c|}
\hline \multicolumn{3}{|c|}{$\begin{array}{l}\text { According to } \\
\text { customer types }\end{array}$} & \multicolumn{3}{|c|}{ Age-wise } & \multicolumn{3}{|c|}{ Gender-wise } & \multicolumn{3}{|c|}{$\begin{array}{l}\text { According to } \\
\text { marital status }\end{array}$} \\
\hline $\begin{array}{c}\text { Types of } \\
\text { Customers }\end{array}$ & No & $\%$ & $\begin{array}{c}\text { Age } \\
\text { Group }\end{array}$ & No & $\%$ & Gender & No & $\%$ & $\begin{array}{c}\text { Marital } \\
\text { status }\end{array}$ & No & $\%$ \\
\hline Depositor & 21 & $53 \%$ & $\begin{array}{c}\text { Less } \\
\text { than } 30\end{array}$ & 0 & $0 \%$ & Male & 30 & $75 \%$ & Married & 25 & $63 \%$ \\
\hline Borrower & 0 & $0 \%$ & $31-40$ & 18 & $45 \%$ & Female & 10 & $25 \%$ & Single & 15 & $37 \%$ \\
\hline $\begin{array}{l}\text { Both/ } \\
\text { Others }\end{array}$ & 19 & $58 \%$ & $\begin{array}{c}41 \\
\text { Above }\end{array}$ & 22 & $55 \%$ & & & & & & \\
\hline Total & 40 & 100 & & 40 & 100 & & 40 & 100 & & 40 & 100 \\
\hline
\end{tabular}

Table 7 reveals that out of 91 respondents 40 respondents did not satisfy on service quality in postmerger phase. Moreover, the borrowers were fully satisfied in post-merger phase, whereas 53 percent of depositors and 48 percent of other customers who were associated with bank through various services were unsatisfied. Similarly, 75 percent of male and 25 percent of female were not satisfied in postmerger phase. Likewise 63 percent of married customers and 37 percent of unmarried customer were not satisfied. The table also shows that customers below 30 years of age were fully satisfied in post-merger phase. 


\section{CONCLUSION}

Merger and acquisition is essential for consolidating banking services, strengthen the banking sector, modernizing services, competing with multinational banks, and enhancing the area of working. Although merger and acquisition procedure is not hassle free, Nepalese banks and financial institutions have been aggressively adopting the strategy of merger and acquisition. Since the entire business depends on customer positive feedback and satisfaction, good customer service is essential in this kind of business.

Customer satisfaction is an ambiguous and abstract concept and the actual manifestation of the state of satisfaction will vary from person to person and product/service to product/service. The state of satisfaction depends on a number of both psychological and physical variables which correlate with satisfaction behaviors such as return and recommend rate. The level of satisfaction can also vary depending on other options the customer may have and other products against which the customer can compare the organization's products. (Nippatlapalli, 2013). The survey reflects that the majority of the customers are fully satisfied in post-merger phase whereas 100 percent responded borrowers are fully satisfied in post-merger phase. Large number of development bank (B class) and finance companies (C class) are merged with A class commercial banks in Nepal which in fact provides loan in lower rate due to low cost of fund in comparison to development banks and finance. It is thus, borrowers seemed more satisfied than depositor. Customer working from longer time with bank may not get personalized service as before so they seemed less satisfied than younger customer in both cases. The survey among 91 respondents working with different merged banks and financial institutions found satisfied in postmerger phase which is similar to the finding of (Nippatlapalli, 2013).

The result suggests that merger and acquisition in Nepalese banks and financial institutions are more benefited to credit clients than depositors. And this finding is similar to (Prompitak, 2009). Prompitak, 2009 concludes merged banks can obtain efficiency gains through mergers and can pass these benefits to their customers in the form of lower lending rates and interest margins.

Another perspective regarding service quality of banks in post-merger found that customers are enjoying better service quality counting advancement in technology. Enhanced capital base has enlarged technology related change covering ATM service, expanded branch network and competitive interest rate. Merger and acquisition seems beneficial for the developing country like Nepal because merger enrich the working area in terms of geographical and technological advancement which ultimately benefit customer expanding branch network. As revealed by the data, 987 numbers of commercial banks' branch as on mid-July, 2010 has been increased to 2,750 numbers as of mid-April, 2018 although the number of BFIs has been decreased.

Customers are optimistic with current merger and acquisition as it has increased capital base which ultimately benefit them through economies of scale. Economies of scale occur when increasing output leads to lower long-run average cost. Thus, the concerned regulatory bodies should be watchful in benefiting customer through economies of scale in service sectors.

\section{REFERENCES}

Ayo, C. K., Ekong, U. O., Fatudimu, I. T., \& Adebiyi, A. A. (2007) M-Commerce implementation in Nigeria: Trends and issues. Journal of Internet Banking and Commerce, 12(2), 1-14.

Chen, Q., \& Vashishtha, R. (2015), The effect of bank merger on corporate information disclosure. Proceeding of 
Colorado Summer Accounting Conference (2014) and AAA Annual Meeting (2014), University of British Columbia.

Clifford, J. F., \& Rowley, J. W. (1999). Canadian banks: Why the mega mergers were stopped. Global Competition Review. Retrieved from: http:/www.mcmillan.ca/Files/Canadian\%20Banks_Why\%20the\%20MegaMergers\%20were\%20Stopped_Mar\%201999.pdf

Conyon, M., Girma, S., Thompson, S., \& Wright, P. (2000). The impact of mergers and acquisitions on company employment in the United Kingdom. Centre for Research and Globalization and Labour Markets, 1(5), 1-25. Retrieved from: http://citeseerx.ist.psu.edu/viewdoc/ download?doi=10.1.1.415.5072\&rep=rep1\&type $=$ pdf

Fashola, O. I. (2014). Customer reactions to bank M\&A: Evidence from the Nigerian banking industry. European Journal of Business and Management, 6(25), 43-65.

Garriga, J. M. (2008). Bank mergers and lending relationships. European Central Bank (Working Paper Series no 934). Retrieved from: https://www.ecb.europa.eu/pub/pdf/scpwps/ecbwp934. pdf?2246f67b5a31f861dc45fe93c4f8321a

Joash, G. O., \& Njangiru, M. J. (2015). The effect of mergers and acquisitions on financial performance of banks: A survey of commercial banks in Kenya. International Journal of Innovative Research and Development, 4(8), 101-113.

Nippatlapalli, A. R. (2013). A study on customer satisfaction of commercial banks: Case study on State Bank of India. Journal of Business and Management, 15(1), 60-86.

Oberg, C. (2008). The importance of customers in mergers and acquisitions (Doctoral dissertation), Linkopong University, Linkopong, Sweden. Retrieved from: http://www.diva-portal.org/smash/get/diva2:18335/ FULLTEXT01.pdfCover

Ojha, S., \& Walsh, J. (2016).Merger policy and its impact on Nepalese banks. International Review of Management and Development Studies, 1(2), 117-134.

Prompitak, D. (2009). The impact of bank mergers and acquisitions on bank behavior (Doctoral dissertation), The University of Birmingham, Birmingham, United Kingdom. Retrieved from: http://etheses.bham. ac.uk/779/

Subrahmanya, P. D. (2011). Merger and acquisition in Indian banking sector: An analytical study (Doctoral dissertation), Jawaharlal Nehru Technological University, India. Retrieved from http://shodhganga. inflibnet.ac.in/handle/10603/4516

Sufian, F. (2004). The efficiency effect of bank mergers and acquisitions in developing economy: Evidence from Malaysia. International Journal of Econometric and Quantitative Studies, 1(4), 53-74.

Wang, S. F., Shih, Y.C., \& Lin, P. L. (2014).The long run performance of Asian commercial bank mergers and acquisition. Scientific Research Publishing, 1(4), 341-359. 